Тарас Печончик

\title{
ОРГАНІЗАЦІЙНО-ЕКОНОМІЧНИЙ МЕХАНІЗМ ФОРМУВАННЯ ДЖЕРЕЛ ФІНАНСУВАННЯ ПІДПРИЕМСТВ ДОРОЖНЬОГО ГОСПОДАРСТВА
}

\author{
Тарас Печончик \\ ОРГАНИЗАЦИОННО-ЭКОНОМИЧЕСКИЙ МЕХАНИЗМ \\ ФОРМИРОВАНИЯ ИСТОЧНИКОВ ФИНАНСИРОВАНИЯ \\ ПРЕДПРИЯТИЙ ДОРОЖНОГО ХОЗЯЙСТВА
}

Taras Pechonchyk

\section{ORGANIZATIONAL-ECONOMIC MECHANISM OF FORMATION OF SOURCES OF FINANCING FOR ROAD SECTOR ENTERPRISES}

У статті розкрито структуру джерел фінансування підприємств дорожнього господарства, затверджену законодавчо на сьогодні, та через багато причин запропоновано впровадження нового підходу до наповнення Державного дорожнього фонду застосувавии принцип «користувач платить» та запропоновано запровадження фінансування за рахунок плати за проїзд, а також запропоновано нову концепцію розподілу фінансових ресурсів.

Ключові слова: дорожне господарство; Державний дорожній фонд; джерела фінансування; структура джерел фінансування; розподіл фінансових ресурсів, плата за проїзд.

Рис.: 1. Табл.: 3. Бібл.: 11.

В статье раскрывается структура источников финансирования предприятий дорожного хозяйства утверждена законодательно сегодня, и по ряду причин предложено внедрение нового подхода к наполнению Государственного дорожного фонда применив принци «пользователь платит» и предложено введение финансирования за счет платы за проезд, а также предложена новая концепция распределения финансовых ресурсов.

Ключевые слова: дорожное хозяйство; Государственный дорожный фонд; источники финансирования; структура источников финансирования; распределение финансовых ресурсов, плата за проезд.

Рис.: 1. Табл.: 3. Библ.: 11.

The article reveals the structure of financing sources of road economy enterprises approved by law today, and for a number of reasons it is proposed to introduce a new approach to the filling of the State Road Fund by applying the principle of "user pays" and it is proposed to introduce financing from the toll, as well as a new concept of distribution of financial resource.

Keywords: road facilities; State Road Fund; sources of financing; structure of sources of financing; distribution of financial resources; toll collection.

Fig.: 1. Table: 3. References: 11.

JEL Classification: R42

Постановка проблеми. Ефективне функціонування автомобільного транспорту можливе, коли кількісний розвиток, якісний рівень і технічний стан автомобільних доріг відповідають вимогам автомобільного транспорту. Таке поєднання якостей, що властиві мережі доріг досягається лише за достатнього рівня фінансування всіх запланованих робіт. Але на сьогодні дорожнє господарство відчуває лише хронічне недофінансування. Крім цього, в умовах стійкої світової тенденції до зменшення споживання нафтопродуктів в автомобільній галузі на фоні стрімкого збільшення рівня автомобілізації суспільства виникає необхідність у масштабних інвестиціях у дорожню інфраструктуру.

Аналіз останніх досліджень і публікацій. Проблемі фінансування дорожнього господарства приділяли увагу А. Безуглий та В. Концева, аналізуючи саму систему фінансування державних суб'єктів господарювання дорожньої галузі [1; 2]; I. Проценко, характеризуючи фінансування дорожнього господарства [3]; О. Жулин, аналізуючи фінансове забезпечення підприємств дорожнього господарства в умовах фінансової децентралізації [4]; С. Шкарлет, І. Хоменко та В. Концева, аналізуючи проблеми формування та фінансування державного дорожнього фонду [5] та багато інших науковців. Інші дослідники аналізували окремі джерела фінансування дорожнього господарства, наприклад, В. Музика досліджував акцизний податок на паливо [6], при цьому питання пов’язані із залученням нових джерел фінансування, майже не досліджувались. 
ФІНАНСОВІ РЕСУРСИ: ПРОБЛЕМИ ФОРМУВАННЯ ТА ВИКОРИСТАННЯ

Виділення недосліджених частин загальної проблеми. Відповідно, фінансування дорожнього господарства за рахунок акцизів на паливо з нафтопродуктів майже вичерпало вже всі свої ресурси. Залучення додаткових джерел фінансування або пошук альтернативних джерел фінансування викликають потребу змінити принципи наповнення Державного дорожнього фонду, тобто переходу до принципу «користувач платить» шляхом запровадження нової структури джерел фінансування, які будуть формуватися користувачами автомобільних доріг за фактичне використання дорожньої мережі залежно від пробігу транспортного засобу, а не від кількості використаного палива.

Мета статті. Головною метою цієї роботи є висвітлення концептуальних засад запровадження нового організаційно-економічного механізму формування джерел фінансування підприємств дорожнього господарства.

Виклад основного матеріалу. 17 листопада 2016 року Верховною Радою України було прийнято Закони «Про внесення змін до Закону України "Про джерела фінансування дорожнього господарства України” щодо удосконалення механізму фінансування дорожньої галузі» [7] та «Про внесення змін до Бюджетного кодексу України щодо удосконалення механізму фінансового забезпечення дорожньої галузі» [8]. Ці законодавчі акти регламентують формування в Державному бюджеті України видатків на фінансування робіт, пов'язаних із будівництвом, реконструкцією, ремонтом і утриманням автомобільних доріг загального користування. Для цих цілей було створено Державний дорожній фонд (ДДФ).

Для наповнення ДДФ було запроваджено такий порядок фінансування дорожнього господарства (табл. 1).

Таблиця 1

Джерела формування Державного дорожнього фонду

\begin{tabular}{|c|c|c|c|c|}
\hline \multirow[t]{2}{*}{ Ч. Ч. } & \multirow[t]{2}{*}{ Види надходжень } & \multicolumn{3}{|c|}{$\begin{array}{l}\text { Розміри зарахувань за ро- } \\
\text { ками, \% }\end{array}$} \\
\hline & & 2018 & 2019 & 2020 \\
\hline 1 & $\begin{array}{l}\text { Акцизний податок з вироблених в Україні пального і транспортних } \\
\text { засобів (Т3) }\end{array}$ & 50 & 75 & 100 \\
\hline 2 & $\begin{array}{l}\text { Акцизний податок з ввезених на митну територію України пально- } \\
\text { го і транспортних засобів }\end{array}$ & 50 & 75 & 100 \\
\hline 3 & Ввізне мито на нафтопродукти і транспортні засоби та шини до них & 50 & 75 & 100 \\
\hline 4 & \multicolumn{4}{|c|}{$\begin{array}{l}\text { Плата за проїзд автомобільними дорогами транспортних засобів та інших самохідних машин } \\
\text { механізмів, вагові або габаритні параметри яких перевищують нормативні }\end{array}$} \\
\hline 5 & \multicolumn{4}{|c|}{$\begin{array}{l}\text { Кошти спеціального фонду Державного бюджету України, отримані шляхом залучення держа- } \\
\text { вою кредитів (позик) від банків, іноземних держав і міжнародних фінансових організацій на роз- } \\
\text { виток мережі та утримання автомобільних доріг загального користування }\end{array}$} \\
\hline 6 & \multicolumn{4}{|c|}{$\begin{array}{l}\text { Плата за проїзд платними автомобільними дорогами загального користування державного значен- } \\
\text { ня, максимальний розмір та порядок справляння якої встановлюються Кабінетом Міністрів України }\end{array}$} \\
\hline 7 & \multicolumn{4}{|c|}{$\begin{array}{l}\text { Інші надходження, передбачені Державним бюджетом України, в обсягах, що визначаються за- } \\
\text { коном про Державний бюджет України на відповідний рік }\end{array}$} \\
\hline 8 & \multicolumn{4}{|l|}{ Плата за передачу доріг у концесію або в оренду } \\
\hline
\end{tabular}

Джерело: сформовано на основі [8].

Відповідно до запровадженої стратегії фінансування ДДФ всі зібрані кошти спрямовуються на фінансування підприємств дорожнього господарства України. За матеріалами Державної цільової економічної програми розвитку автомобільних доріг загального користування державного значення на 2018-2022 роки розмір фінансування становитиме близько 322 млрд грн [9] (табл. 2). 
ФІНАНСОВІ РЕСУРСИ: ПРОБЛЕМИ ФОРМУВАННЯ ТА ВИКОРИСТАННЯ

Таблиця 2

Джерела фінансування дорожнього господарства

\begin{tabular}{|l|c|c|c|c|c|c|}
\hline \multirow{2}{*}{ Джерела фінансування } & \multirow{2}{*}{$\begin{array}{c}\text { Обсяг } \\
\text { фінансування, } \\
\text { млн грн }\end{array}$} & $\mathbf{2 0 1 8}$ & $\mathbf{2 0 1 9}$ & $\mathbf{2 0 2 0}$ & $\mathbf{2 0 2 1}$ & $\mathbf{2 0 2 2}$ \\
\cline { 5 - 7 } & 201108,42 & 26327,77 & 35983,81 & 45011,43 & 46132,37 & 47653,04 \\
\hline $\begin{array}{l}\text { Державний бюджет, } \\
\text { у тому числі: }\end{array}$ & & & & & \\
\hline $\begin{array}{l}\text { кошти спеціального фонду } \\
\text { державного бюджету } \\
\text { (державний дорожній фонд) }\end{array}$ & 193149,62 & 20025,46 & 35217,33 & 44121,43 & 46132,37 & 47653,04 \\
\hline $\begin{array}{l}\text { кошти загального фонду } \\
\text { державного бюджету }\end{array}$ & 7958,79 & 6302,31 & 766,48 & 890 & - & - \\
\hline $\begin{array}{l}\text { кошти міжнародних } \\
\text { фінансових організацій }\end{array}$ & 20255,47 & 3722,27 & 4463,64 & 4440 & 3910,30 & 3719,25 \\
\hline $\begin{array}{l}\text { Інші джерела, зокрема } \\
\text { й кошти інвесторів }\end{array}$ & 100781,31 & - & 514,1 & 18043,47 & 36051,17 & 46172,58 \\
\hline Усього & 322145,19 & 30050,04 & 40961,55 & 67494,90 & 86093,83 & 97544,87 \\
\hline
\end{tabular}

Джерело: наведено за [9].

Але цього обсягу фінансування не достатньо, оскільки мережа автомобільних доріг загального користування України була сформована ще за радянських часів, а за останні 20 років різко змінився якісний склад транспортних потоків на автомобільних дорогах України. А крім цього, у зв'язку з обмеженим фінансуванням, близько 90 \% автомобільних доріг загального користування не ремонтували понад 30 років, тому майже $39 \%$ доріг загального користування не відповідають сучасним вимогам за міцністю та понад $50 \%$ за рівністю [10].

Крім нагальних поточних потреб із фінансування дорожнього господарства, ще існує така складова витрат, як фінансування видатків на виконання боргових зобов'язань, взятих Укравтодором у міжнародних фінансових організацій. Так, на сьогодні кредитний портфель Укравтодору має такі складові:

- Третій кредит Свропейського Банку Реконструкції та Розвитку - сума 200 млн євро;

- Кредит Свропейського Інвестиційного Банку - сума 200 млн євро;

- Кредит Світового банку - сума 400 млн дол. США;

- IV кредит Свропейського Банку Реконструкції та Розвитку - сума 450 млн євро;

- Другий кредит Свропейського Інвестиційного Банку - 450 млн євро;

- Другий кредит Світового банку - сума 450 млн дол. США;

- Третій кредит Світового банку - сума 338 млн дол. США.

- Частину отриманих кредитів було погашено за період до 2020 року, а з 2020 року видатків на виконання боргових зобов'язань залишилось на суму 78,9 млрд грн (табл. 3).

Таблиця 3

Сума видатків на виконання боргових зобов'язань, тис. грн

\begin{tabular}{|c|c|c|c|c|c|c|c|c|}
\hline Рік & 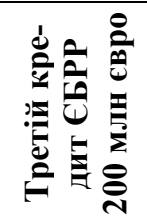 & 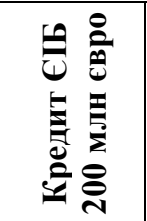 & 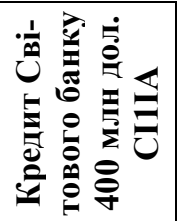 & 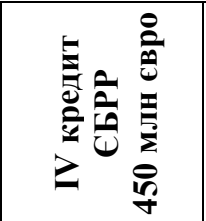 & 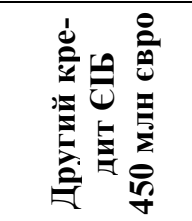 & 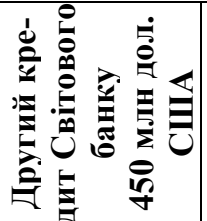 & 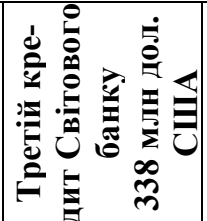 & Разом \\
\hline 1 & 2 & 3 & 4 & 5 & 6 & 7 & 8 & S \\
\hline 2020 & 593364,5 & 2249,6 & 729179,3 & 1769369,234 & 559121,97 & 1364686,6 & 92662,1 & 561063 \\
\hline 2021 & 53501,6 & 585139,5 & 805262,9 & 2200921,394 & 747556,5196 & 1721115,1 & 223862,6 & 6937 \\
\hline 2022 & 322849,9 & 578767,1 & 792252,6 & 2165232,542 & 755401,8555 & 1685526,4 & 1288798,6 & 7588829 \\
\hline 2023 & 0 & 568557,6 & 773486,3 & 115111,418 & 745929,3499 & 1636238,3 & 1302548,7 & 7141871,67 \\
\hline 2024 & 0 & 558525,1 & 755516,9 & 2065264,931 & 786437,5952 & 1587692,9 & 1266567,9 & 7020005,33 \\
\hline 2025 & 0 & 548138,7 & 735953,8 & 2014869,171 & 1119904,174 & 1538202,2 & 1228873,6 & 7185941,65 \\
\hline 2026 & 0 & 537929,2 & 717187,5 & 0 & 1394626,385 & 1487901,4 & 1192036,1 & 5329680,59 \\
\hline
\end{tabular}


Закінчення табл. 3

\begin{tabular}{|r|c|c|c|c|c|c|c|c|}
\hline 1 & 2 & 3 & 4 & 5 & 6 & 7 & 8 & 9 \\
\hline $\mathbf{2 0 2 7}$ & 0 & 527719,8 & 698421,2 & 0 & 1369743,068 & 1439085,9 & 1155198,5 & 5190168,47 \\
\hline $\mathbf{2 0 2 8}$ & 0 & 517575,4 & 680246,2 & 0 & 1345505,138 & 1390000,4 & 1118814,1 & 5052141,24 \\
\hline $\mathbf{2 0 2 9}$ & 0 & 507300,9 & 660888,7 & 0 & 1319976,437 & 676399 & 1081523,5 & 4246088,54 \\
\hline $\mathbf{2 0 3 0}$ & 0 & 330944,1 & 642122,4 & 0 & 1295093,121 & 0 & 1044686 & 3312845,62 \\
\hline $\mathbf{2 0 3 1}$ & 0 & 82074,4 & 623356,1 & 0 & 1270209,805 & 0 & 1007848,4 & 2983488,71 \\
\hline $\mathbf{2 0 3 2}$ & 0 & 0 & 604975,4 & 0 & 1148687,188 & 0 & 960689,8 & 2714352,39 \\
\hline $\mathbf{2 0 3 3}$ & 0 & 0 & 585823,6 & 0 & 890317,1024 & 0 & 0 & 1476140,7 \\
\hline $\mathbf{2 0 3 4}$ & 0 & 0 & 567057,3 & 0 & 807313,4664 & 0 & 0 & 1374370,77 \\
\hline $\mathbf{2 0 3 5}$ & 0 & 0 & 548291 & 0 & 791354,8308 & 0 & 0 & 1339645,83 \\
\hline $\mathbf{2 0 3 6}$ & 0 & 0 & 529704,6 & 0 & 763291,441 & 0 & 0 & 1292996,04 \\
\hline $\mathbf{2 0 3 7}$ & 0 & 0 & 510758,5 & 0 & 735289,5552 & 0 & 0 & 1246048,06 \\
\hline $\mathbf{2 0 3 8}$ & 0 & 0 & 493013,4 & 0 & 1375630,747 & 0 & 0 & 1868644,15 \\
\hline Pa30M & 1569716 & 5844921,4 & 12453497,7 & 12330768,69 & 19221389,75 & 14526848,2 & 12964109,9 & 78911252,0 \\
\hline
\end{tabular}

Існуючі джерела фінансування Дорожнього фонду не можуть забезпечити необхідний для нашої економіки рівень розвитку мережі доріг. Тому питання фінансування автомобільних доріг загального користування $є$ досить актуальним у наш час. На наше переконання, потрібно запровадити нову структуру джерел фінансування та застосувати нову концепцію розподілу фінансових ресурсів. Потрібно змінити підхід, коли формування надходжень до Державного дорожнього фонду відбувається переважно за рахунок акцизів на паливо із нафтопродуктів, на альтернативні джерела фінансування, застосувавши принцип «користувач платить» шляхом запровадження спеціальних цільових дорожніх податків, які сплачуються користувачами автомобільних доріг за фактичне використання дорожньої мережі залежно від пробігу транспортного засобу, а не від кількості використаного палива (рис. 1).

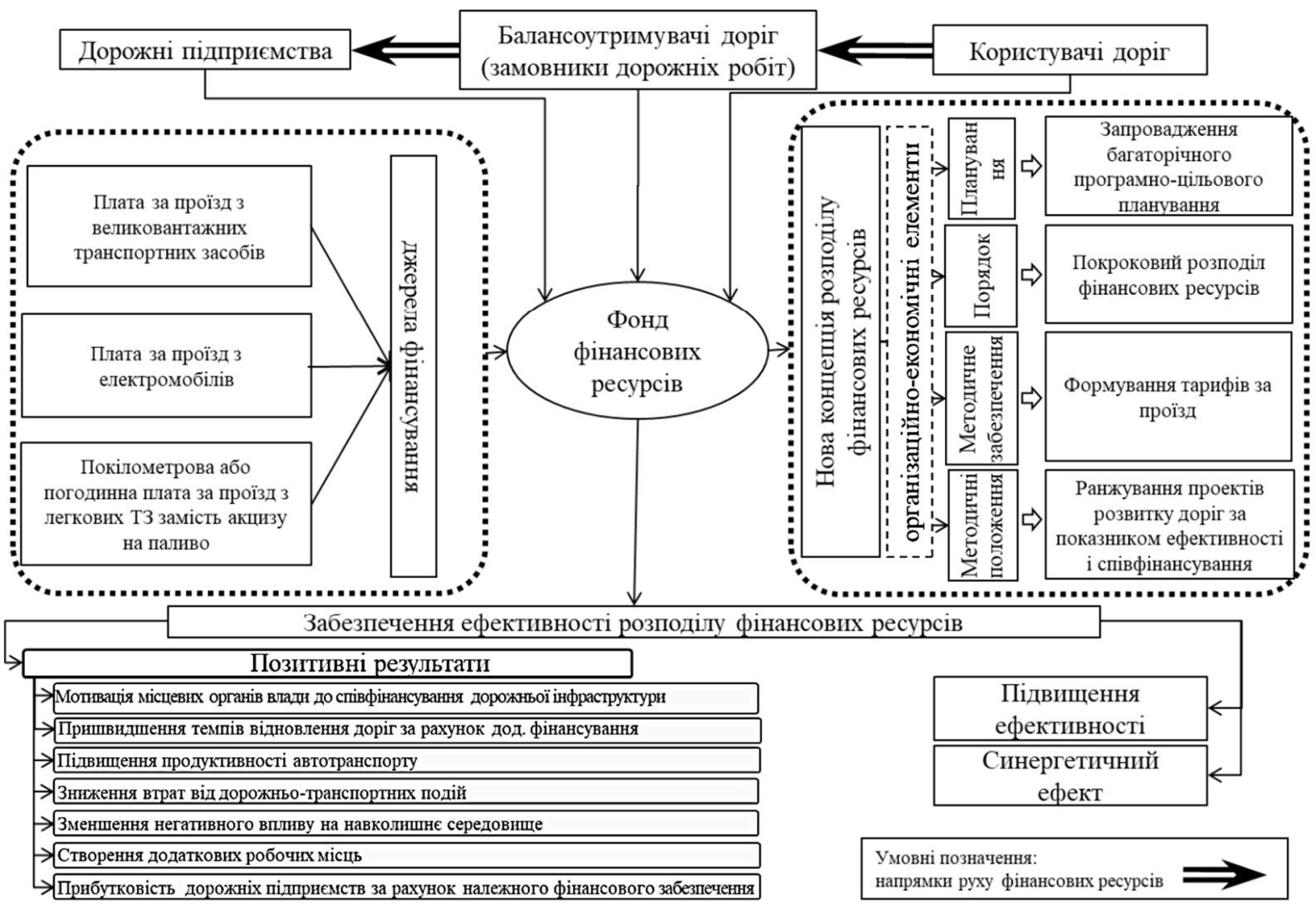

Рис. 1. Організаційно-економічний механізм залучення та розподілу фінансових ресурсів у дорожньому господарстві 
ФІНАНСОВІ РЕСУРСИ: ПРОБЛЕМИ ФОРМУВАННЯ ТА ВИКОРИСТАННЯ

Зміна підходів до вибору джерел надходжень фінансових ресурсів, інструментів їх залучення та використання в дорожньому господарстві, забезпечить відповідність розвитку підприємств дорожнього господарства потребам користувачів автомобільних доріг в умовах збільшенні рівня «автомобілізації» населення й руйнівного впливу від транспортних засобів на дорожню інфраструктуру.

Користувачам автомобільних доріг потрібна добре розвинена транспортна інфраструктура, відповідно, першим кроком у пошуках додаткового фінансування потреб підприємств дорожнього господарства є звернення до тих, хто ці дороги використовує. Користувачі мережі автомобільних доріг можуть платити безпосередньо, наприклад, шляхом зворотного зв'язку, або опосередковано, наприклад, шляхом податку на пальне. Найбільш справедливими зборами з користувачів автомобільних доріг, які включають і економічну й соціальну складову є такі, що пов'язані з пробігом та руйнівним впливом на дороги.

Введення додаткової плати за проїзд у вигляді плати за пройдений кілометр, чи в іншій формі, може бути ключовим економічним інструментом транспортної політики держави. Наша країна має транзитні шляхи. Тому для розвитку торгівлі, підтримки вітчизняного виробника та у зв'язку з географічним розташуванням нашої країни (Україну використовують як міжнародні транспортні коридори для доступу до країн Європи та Азіі) можливо встановити різну плату для вітчизняних та закордонних транспортних засобів, що рухаються транзитом через нашу територію. Витрати будуть доцільними для обгрунтування рішення про необхідність здійснення незначних і неважливих поїздок. Вони будуть здійснюватися тільки тоді, коли користь, що буде запланована, перевищуватиме витрати понесені за кожний кілометр цієї поїздки.

Також запровадження додаткових зборів за проїзд матиме вплив на розвиток туристичної галузі. Досвід показує, що належне утримання доріг та дорожньої інфраструктури набагато дешевше, ніж їх ремонти. Відповідно, якщо плата, що буде спрямовуватися надалі на утримання доріг покращить їх стан, то це збільшить пасажиропотік, що, у свою чергу, приведе до розвитку туристичної галузі.

Також одним із основних факторів, на який матиме вплив запровадження додаткового альтернативного фінансування до ДДФ, є існування вітчизняного виробництва ТЗ. Необхідність підтримки вітчизняної автомобільної галузі шляхом заохочення продажів ТЗ вітчизняного виробництва, може справити політичний тиск на придбання імпортованих ТЗ.

Власники та користувачі електромобілів та Т3 з альтернативними до двигунів внутрішнього згорання силовими установками (надалі власники та користувачі екологічного транспорту) є учасниками дорожнього руху та постійно використовують мережу автомобільних доріг. При цьому електромобіль рухаючись цією мережею спричиняє ряд збитків. Якщо власники Т3 із двигунами внутрішнього згорання компенсують свій вплив на мережу автомобільних доріг при іiї використанні шляхом сплати акцизних податків, то власники та користувачі екологічного транспорту не компенсують цих збитків ніяким механізмом. До всіх користувачів мережі автомобільних доріг повинен застосовуватися єдиний фіскальний принцип (принцип соціальної справедливості) компенсація збитків тими, хто їх наносить. Відповідно потрібно запровадити плату за проїзд із власників екологічно чистого транспорту.

Власники та користувачі екологічно чистих Т3 та кожен користувач мережі автомобільних доріг, при сплаті за проїзд цією мережею можуть та повинні розраховувати на належні утримання, ремонт, покращення чи розширення цієї мережі, тому потрібно запровадити нову концепцію розподілу фінансових ресурсів.

Для реалізації цього завдання потрібно запровадити багаторічне програмно-цільове планування, що покращить розподіл ресурсів та їх ефективне використання в балансоутримувачів доріг та дорожніх підприємств. Також потрібно застосувати покроковий 
ФІНАНСОВІ РЕСУРСИ: ПРОБЛЕМИ ФОРМУВАННЯ ТА ВИКОРИСТАННЯ

розподіл фінансових ресурсів із чітким та прозорим механізмом, що буде виключати корупційні схеми та можливості зловживань. Крім цього, одним із головних завдань при реалізації нової концепції розподілу фінансових ресурсів $\epsilon$ формування тарифів на проїзд. Так, країни Західної Європи, визначаючи розмір тарифу, посилаються на витратний метод, що передбачає встановлення плати на рівні відшкодування витрат понесених за час терміну експлуатації дороги з урахуванням іiі протяжності, прогнозованої інтенсивності руху та видів Т3. Інший підхід застосовують більшість країн, що користувалися раніше радянськими методиками. Ця система спрямована на забезпечення соціальної функції тарифу, що передбачає встановлення низької плати за проїзд, яка кореспондується з низькою платоспроможністю населення і забезпечує доступність відповідних послуг. При цьому ігноруються такі показники, як витрати на будівництво й утримання дороги, прибуток держави, концесіонера чи власника дороги, термін окупності. Альтернативною до двох попередніх є «Сінгапурська модель» [12], яка передбачає прискорену окупність проєкту, що зумовлює встановлення високих тарифів за проїзд мережею доріг.

Крім зазначеного вище, на нашу думку, потрібно впровадити ранжування проєктів розвитку доріг за показниками ефективності та співфінансування. До виконання потрібно приймати проєкти з високими показниками ефективності, що забезпечить їх окупність, а крім цього, пріоритетними повинні стати об’єкти, в яких спостерігається високий рівень співфінансування проєктів будівництва, реконструкції чи ремонтів із боку місцевих органів влади. Участь у процесі фінансування проєктів фінансових ресурсів користувачів доріг чи балансоутримувачів поряд із ресурсами ДДФ забезпечить підвищення ефективності використання доріг, розвитку регіонів та реалізації проєктів, дійсно потрібних користувачам.

Висновки і пропозиції. Впровадження нової структури фінансування дорожнього господарства не тільки впливатиме на розвиток підприємств дорожнього господарства, а i їх утримання в належному стані, а ще і стане інструментом для керування промисловою та торговельною політиками, туризмом, фінансовою політикою, думкою та настроями громадськості тощо. Також це зменшить навантаження на ДДФ шляхом запровадження співфінансування реалізації проєктів будівництва, реконструкції чи ремонтів дорожньої інфраструктури. Цей процес у свою чергу підвищить темпи відновлення та будівництва доріг за рахунок використання додаткового фінансування. Також, рух автотранспорту дорогами із кращою якістю, скоротить час у дорозі та зменшить витрати автовласників, що підвищить його продуктивність. Покращена дорожня інфраструктура зменшить витрати від дорожньо-транспортних пригод та зменшить екологічне навантаження на навколишнє середовище. Ефективний та вчасний правильний розподіл фінансових ресурсів між дорожніми підприємствами також забезпечить їхню прибутковість.

\section{Список використаних джерел}

1. Безуглий, А. О. Аналіз системи фінансування державних суб'єктів господарювання дорожньої галузі. Проблеми і перспективи розвитку підприємнищтва. 2014. № 1. С. 29-32.

2. Хоменко І. О., Концева В. В., Безуглий А. О. Сучасний стан та особливості фінансування дорожньої галузі. Науковий вісник Полісся. 2017. № 4 (12), ч. 2. С. 201-205.

3. Проценко I. А. Фінансування дорожнього господарства: проблеми та можливе вирішення. Дороги і мости. 2006. № 5. С. 378-384.

4. Жулин О. В. Фінансове забезпечення підприємств дорожнього господарства в умовах фінансової децентралізації. Вісник Наџіонального транспортного університету. 2014. № 30(2). С. 57-65.

5. Шкарлет С. М., Хоменко І. О., Концева В. В. Актуальні проблеми формування та фінансування державного дорожнього фонду. Науковий вісник Полісся. 2017. № 3 (11), ч. 1. С. 16-20.

6. Музика В. Акцизний податок на паливо як джерело фінансування дорожнього господарства. Actual problems of ukraine's economic system functioning. 2015. C. 146-147. 
ФІНАНСОВІ РЕСУРСИ: ПРОБЛЕМИ ФОРМУВАННЯ ТА ВИКОРИСТАННЯ

7. Про внесення змін до Закону України «Про джерела фінансування дорожнього господарства України» щодо удосконалення механізму фінансування дорожньої галузі : Закон України від 17.11.2016 № 1762-VIII (зі змінами). URL: https://zakon.rada.gov.ua/laws/show/1762-19.

8. Про внесення змін до Бюджетного кодексу України щодо удосконалення механізму фінансового забезпечення дорожньої галузі : Закон України від 17.11.2016 № 1763-VIII (зі змінами). URL: https://zakon.rada.gov.ua/laws/show/1763-19.

9. Про затвердження Державної цільової економічної програми розвитку автомобільних доріг загального користування державного значення на 2018-2022 роки : Постанова Кабінету Міністрів України від 21.03.2018 № 382-2018-п (зі змінами). URL: https://zakon.rada.gov.ua/laws/ show $/ 382-2018-\%$ D0\%BF.

10. Пояснювальна записка до проекту Закону України «Про внесення змін до статті 4 Закону України «Про джерела фінансування дорожнього господарства України» щодо додаткових джерел наповнення територіальних дорожніх фондів». URL: http://search.ligazakon.ua/1_doc2.nsf/ link1/GI01225A.html.

11. Ortmann S. The "Beijing consensus" and the "Singapore model": unmasking the myth of an alternative authoritarian state-capitalist model. In China's Economic Dynamics. Routledge, 2013. P. 97-120.

\section{References}

1. Bezuhlyy, A. O. (2014). Analiz systemy finansuvannya derzhavnykh sub'yektiv hospodaryuvannya dorozhn'oyi haluzi [Analysis of the financing system of state entities managing the road industry]. Problemy $i$ perspektyvy rozvytku pidpryyemnytstva - Problems and prospects of entrepreneurship development, 1, 29-32 [In Ukrainian].

2. Khomenko, I. O., Kontseva, V. V., Bezuglyi, A. O. (2017). Suchasnyi stan ta osoblyvosti finansuvannia dorozhnoi haluzi [Current state and features of financing of the road sector]. Scientific bulletin of Polissia - Scientific Bulletin of Polissia, 12 [In Ukrainian].

3. Protsenko, I. A. (2006). Finansuvannya dorozhnoho hospodarstva: problemy ta mozhlyve vyrishennia [Road Financing: Problems and Possible Solutions]. Dorohy i mosty - Roads and bridges, 5, 378-384 [In Ukrainian].

4. Zhulyn, O. V. (2014). Finansove zabezpechennya pidpryyemstv dorozhn'oho hospodarstva v umovakh finansovoyi detsentralizatsiyi [Financial support of road enterprises in the conditions of financial decentralization]. Visnyk Natsionalnoho transportnoho universytetu - Bulletin of the National Transport University, 30 (2), 57-65 [In Ukrainian].

5. Shkarlet, S. M., Khomenko, I. O., Kontseva, V. V. (2017). Aktualni problemy formuvannia ta finansuvannia derzhavnoho dorozhnoho fondu [Actual problems of formation and funding of the stateroad funds]. Naukovyi visnyk Polissia - Scientific Bulletin of Polissia, 3 (1), $16-20$ [In Ukrainian].

6. Muzyka, V. (2015). Aktsyznyi podatok na palyvo yak dzherelo finansuvannia dorozhnoho hospodarstva [Excise tax on fuel as a source of financing for the road industry]. Actual problems of Ukraine's economic system functioning, 146-147 [In Ukrainian].

7. Pro vnesennya zmin do Zakonu Ukrayiny «Pro dzherela finansuvannya dorozhnoho hospodarstva Ukrainy» shchodo udoskonalennia mekhanizmu finansuvannia dorozhnoi haluzi [On Amendments to the Law of Ukraine «On Sources of Financing of the Road Economy of Ukraine» on Improvement of the Road Financing Mechanism]. № 1762-VIII (17.11.2016). Retrieved from https://zakon.rada.gov.ua/laws/show/1762-19.

8. Pro vnesennia zmin do Biudzhetnoho kodeksu Ukrainy shchodo udoskonalennia mekhanizmu finansovoho zabezpechennia dorozhnoi haluzi [On Amendments to the Budget Code of Ukraine on Improvement of the Road Financial Mechanismi]. № 1763-VIII (17.11.2016). Retrieved from https://zakon.rada.gov.ua/laws/show/1763.

9. Pro zatverdzhennya Derzhavnoi tsilovoi ekonomichnoi prohramy rozvytku avtomobilnykh dorih zahalnoho korystuvannia derzhavnoho znachennia na 2018-2022 roky [On approval of the State Target Economic Program for the Development of Public Roads of Public Importance for 2018-2022]. № 382-2018-p 21.03.2018. Retrieved from https://zakon.rada.gov.ua/laws/show/382-2018-\%D0\%BF. 
ФІНАНСОВІ РЕСУРСИ: ПРОБЛЕМИ ФОРМУВАННЯ ТА ВИКОРИСТАННЯ

10. Poiasnyuvalna zapyska do proektu Zakonu Ukrainy «Pro vnesennia zmin do statti 4 Zakonu Ukrainy "Pro dzherela finansuvannia dorozhnoho hospodarstva Ukrainy» shchodo dodatkovykh dzherel napovnennia terytorialnykh dorozhnikh fondiv"» [Explanatory Note to the Draft Law of Ukraine «On Amendments to Article 4 of the Law of Ukraine" On Sources of Financing the Road Economy of Ukraine "on Additional Sources of Replenishment of Territorial Road Funds"»] Retrieved from http://search.ligazakon.ua/1_doc2.nsf/link1/GI01225A.html.

11. Ortmann, S. (2013). The "Beijing consensus" and the "Singapore model": unmasking the myth of an alternative authoritarian state-capitalist model. In China's Economic Dynamics (pp. 97-120). Routledge. [In England].

Печончик Тарас Іларіонович - аспірант кафедри «Фінанси, облік і аудит», Національний транспортний університет (вул. М. Омеляновича-Павленка, 1, м. Київ, 01010, Україна).

Печончик Тарас Илларионович - аспирант кафедры «Финансы, учет и аудит», Национальный транспортный университет (ул. Н. Омеляновича-Павленка, 1, г. Киев, 01010, Украина).

Pechonchyk Taras - PhD Student of the Department of Finance, Accounting and Auditing, National Transport University (1 M. Omelyanovych-Pavlenka Str., 01010 Kyiv, Ukraine).

E-mail: taras905@gmail.com

ORCID: https://orcid.org/0000-0003-3093-6822 